\title{
EVALUATION OF SOIL AND WATER CONSERVATION PROJECTS THROUGH ESTIMATION OF EROSION INTENSITY BY GEOMORPHOLOGICAL MODELLING (CASE STUDY OF SAFAROUD WATERSHED, MAZANDARAN PROVINCE, IRAN)
}

\author{
PALHAM ABBASI, A. ${ }^{1}$ - AHMADI, $\mathrm{H}{ }^{*}$ - MOHAMMAD KHAN, SH. ${ }^{2}-$ MOEINI, A. ${ }^{1}$ \\ ${ }^{I}$ Department of Watershed Management, Sciences and Research Branch, \\ Islamic Azad University, Tehran, Iran \\ ${ }^{2}$ Department of Physical Geography, University of Tehran, Tehran, Iran \\ *Corresponding author \\ e-mail:h-ahmadi@srbiau.ac.ir \\ (Received 24 $4^{\text {th }}$ Feb 2017; accepted $18^{\text {th }}$ May 2017)
}

\begin{abstract}
Various projects have been implemented to control erosion and conserve soil/water resources. One method used to evaluate soil and water conservation projects involves mapping of erosion across a region. This study employed geomorphological methods and the so-called Analytic Hierarchy Process (AHP) technique to prepare an erosion map of Safaroud watershed in Mazandaran Province, Iran, with the aim of evaluating soil and water conservation projects. The erosion map of the region under study was compiled at two reference points in time: prior to project implementation (1994) and after projection completion (2014). The map for the erosion trend of each working unit was prepared either as positive or negative, based on a comparative examination of the erosion map for each working unit against another working unit at the two reference points in time. The effectiveness of projects in each working unit was evaluated by matching the erosion map compiled through maps of soil and water conservation projects implemented across the region. After the statistical analysis of erosion intensities before and after project implementation, the results indicated no significant relationship between the erosion intensities before and after project implementation, at an error level of 0.05 . However, most of the units where the erosion trends turned upwards were located along the margins of villages, mainly due to unsystematic development of the rural areas. Erosion intensities were reduced in most of the forested areas, indicating effectiveness of project implementation in those areas.
\end{abstract}

Keywords: soil and water conservation, erosion trend, criteria, AHP, Safaroud

\section{Introduction}

Soil erosion is one of the most serious environmental problems in the modern world as it acutely threatens agriculture, natural resources and the environment (Onyando et al., 2005). In terms of erosion, Iran is in a poor state. Average soil loss in Iran is estimated to be around one billion tonnes per year (Arab Khedri, 2014).

So far, several measures have been taken to prevent soil erosion. It is, however, critical to evaluate the efficacy of the conservation projects. Nevertheless, soil and water conservation measures also have ecological and social impacts that cannot be easily quantified in monetary terms (Tenge, 2005).

Various models are employed to evaluate actions taken to conserve soil and water resources. In this respect, native models can be effective. This study intended to evaluate soil and water conservation projects by focusing on erosion intensity as the main effective parameter. For this purpose, a geomorphological model (Ahmadi, 2006) was used to estimate the intensity of erosion. 
The effective implementation of soil conservation measures requires a previously undertaken spatially distributed erosion hazard and risk assessment (Moussa et al., 2002, Souchère et al., 2005). In order to calculate a region's erosion hazard, one should study regional soil conditions, climatic characteristics, vegetation, terrain, ground cover, etc. Various papers have proposed methods to evaluate erosion hazard and risk based on different parameters, such as morphometric variables (Jozefaciuk and Jozefaciuk, 1993), sediment yield information (Rooseboom and Annandale, 1981) and rainfall erosion indices (Hudson, 1981).

In this geomorphological model, different criteria have been used for mapping erosion. Using advanced remote sensing (RS) and geographical information system (GIS) techniques and modelling approaches, investigators also developed methods for erosion hazard and risk evaluation, such as integrated and systematic approaches (Tian et al., 2009; Vezina et al., 2006), fuzzy and artificial neural-network evaluation methods (He, 1999), geostatistical multivariate approaches (Conoscenti et al., 2008), soft computing method (Gournellos et al., 2004), and analytical risk evaluation methods (Masoudi et al., 2006; Wu and Wang, 2007).

The reliability of susceptibility maps depends mostly on the amount and quality of available data, working scale, and the choice of appropriate methodology for analysis and modelling (Sar et al., 2016).

Early attempts had defined susceptibility classes by qualitatively overlaying geological and morphological slope attributes onto soil erosion inventories (Nielsen et al., 1979). However, more sophisticated assessment methods have been reported in recent years, e.g. Analytical Hierarchy Process (AHP), bivariate, multivariate, logistic regression, fuzzy logic, or Artificial Neural Network (ANN) (Chacón et al., 2006; Lee et al., 2006; Akgun et al., 2008; Oh et al., 2009). The geomorphological model proposed by Ahmadi, 2006 is a qualitative model quantified by AHP and GIS techniques (Ahmadi et al., 2009; Mohammad Khan, 2009; Angabini, 2014).

The application of the AHP method, developed by Saaty (2008) for soil erosion susceptibility mapping, has been found in e.g., Barredo et al. (2000) and Yagi (2003), while the use of a Weighted Linear Combination (WLC) technique was reported by Ayalew et al. (2004).

Using the AHP technique and repetition rate, an erosion sensitivity map has been prepared for Keleghai watershed in India. Based on this study, comprehensive erosion susceptibility management strategies were anticipated for efficient management of present and future erosion disasters in the area (Sar et al., 2016).

In 2014, a survey was conducted through Multi-Criteria Analysis (MCA) to evaluate the soil and water conservation activities in highlands of northwest Ethiopia. In this study, MCA was employed to evaluate soil and water conservation activities through several qualitative criteria and weighting factors. It was found that the degree of importance for each criterion in the evaluation of projects depended greatly on the physical factor of slope (Teshome et al., 2014).

In 1990, Safaroud watershed experienced a flood, with flow rate of $296 \mathrm{~m}^{3} / \mathrm{s}$, causing considerable human and financial losses (Engineers, 1994). In order to prevent floods and curtail soil degradation across the region, the Safaroud Watershed Comprehensive Project was completed in 1994. Based on the results of this project, several soil and water conservation measures were taken up across the region. 
This study is an attempt to evaluate the effectiveness of the soil and water conservation activities already undertaken in the region. For this purpose, the geomorphological method by Ahmadi (2006) was used to map erosion intensity.

The erosion intensity map was compiled at two reference points in time, namely, prior to the project implementation (1994) and after the projection completion (2014). By comparing these maps, the erosion trend in each working unit and efficacy of each project were determined.

\section{Materials and methods}

\section{Study area}

Safaroud watershed is located in the west of Mazandaran Province (northern Iran) and covers an area of 13,551 hectares. Approximately 9,500 hectares of the region are forested, while 4,051 hectares are covered by rangelands. There are over 20 villages within the watershed region. Elevation of the highest across the watershed is 3,560 metres above sea level, whereas the lowest point is as low as 76 metres above sea level (Fig. 1).

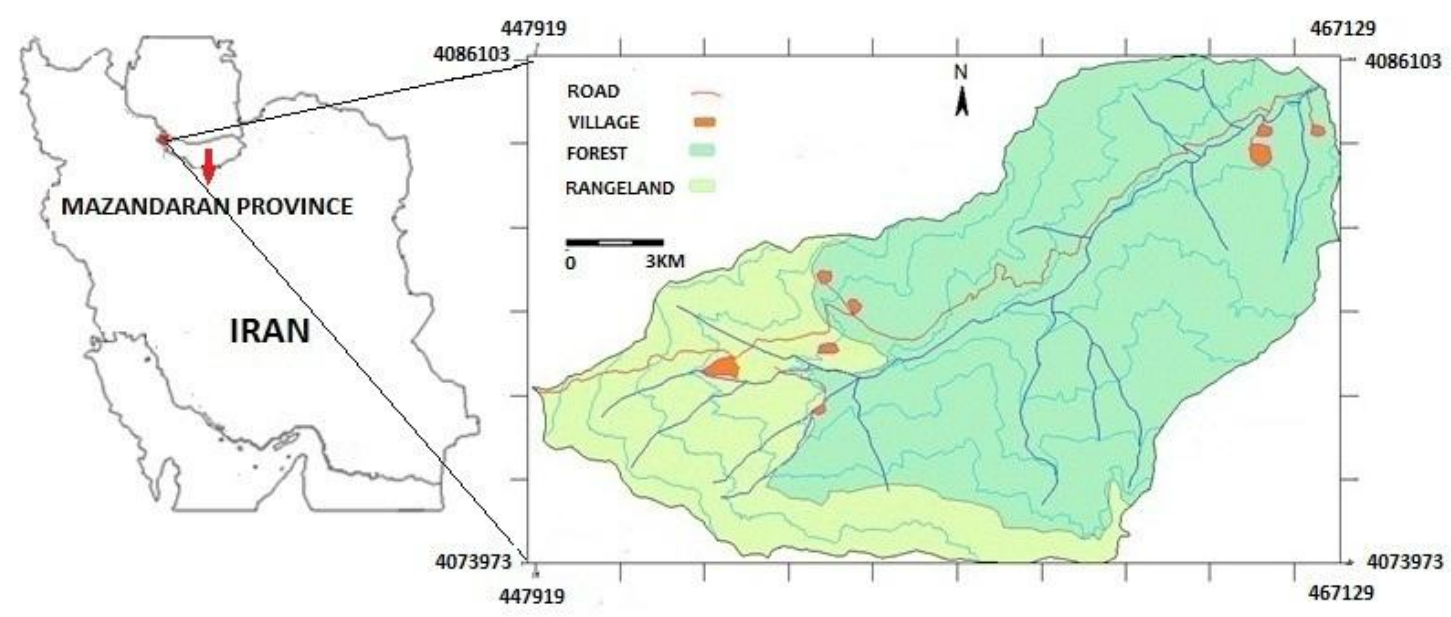

Figure 1. Map of study area in Mazandaran province, Iran.

\section{Geomorphological model}

This model explores several criteria, including physiographic, geology, soil, climate, hydrology, vegetation, land use and socio-economic characteristics. In addition, the model takes erosion status across the region as a contributing factor (Ahmadi, 2006).

This qualitative model has already been quantified by different researchers, who have also examined it in different parts of Iran. The results obtained from this model were matched against the observational data, demonstrating great accuracy of the proposed model (Mosayebi et al., 2008). 


\section{Data collection}

This study intended to compare erosion intensities at two reference points in time, namely, before and after the implementation of soil and water conservation projects, across the study area - so as to evaluate how effective each project has been. This study was conducted in two stages.

Firstly, the erosion intensity map was prepared through a geomorphological method at reference times (i.e. before and after project implementation, 1994). This stage involved available reports and maps for Safaroud Watershed Comprehensive Project (1994).

For mapping the erosion intensities at the latter reference time (i.e. after project implementation, 2014), data was collected from the following sources:

- Sheets of topographic maps of Ramsar and Javaherdeh at a scale of 1:50,000,

- Landsat 8 satellite images,

- Field study, and

- Compilation of maps and information for soil and water conservation projects implemented across the region.

\section{Preparation of information layers}

After compiling the basic information regarding the region, several maps were produced, based on the criteria under study: geomorphological map and regional map of the working units at the two reference times. Table 1 presents available criteria and options in the geomorphological model of the present study, which were adapted to map erosion.

Table 1. Criteria, indices and options under study.

\begin{tabular}{|c|c|c|}
\hline Criterion & Index & Options \\
\hline \multirow{2}{*}{ Physiography } & Slope & $<10,10-20,20-30,30-40,>40 \%$ \\
\hline & Aspect & $\mathrm{N}, \mathrm{E}, \mathrm{S}, \mathrm{W}$ \\
\hline \multirow{2}{*}{ Climate } & Precipitation & $\begin{array}{c}600-700,700-800,800-900,900-1000,1000-1100,1100- \\
1200 \mathrm{~mm}\end{array}$ \\
\hline & $\begin{array}{l}\text { Precipitation } \\
\text { form }\end{array}$ & Snow- Rain \\
\hline Geology & Formation type & Qal- Qs- Javaherdeh- Shemahak- Nesen-Tizkooh- Elika \\
\hline Soil & $\begin{array}{l}\text { Soil texture } \\
\text { Infiltration }\end{array}$ & $\begin{array}{l}\text { Loam-Sandy Loam- Clay Loam- Clay- Silty Clay- Loamy Sand } \\
\text { Relatively high- Moderate- Relatively low }\end{array}$ \\
\hline \multirow{2}{*}{ Vegetation } & $\begin{array}{l}\text { Germination } \\
\text { form }\end{array}$ & Shrub- Grass \\
\hline & $\begin{array}{l}\text { Coverage } \\
\text { percentage }\end{array}$ & $<30-30-75->75 \%$ \\
\hline Land Use & $\begin{array}{c}\text { Type and } \\
\text { severity of } \\
\text { exploitation }\end{array}$ & $\begin{array}{l}\text { Good pasture, Moderate pasture, Degraded forest, semi- } \\
\text { degraded forest, good forest, garden, village, rock }\end{array}$ \\
\hline
\end{tabular}

After preparing the information layer for indices, the maps were divided into several classes, based on their options. 
The geomorphological maps from years prior to project implementation (1994) were obtained from corresponding reports, while the geomorphological map for the latter reference time (2014) was compiled based on satellite images and field studies.

\section{Assigning weights to layers}

The relative preferences of options were specified and their pair-wise comparison matrices were completed through the application of AHP technique, based on the ratio of area under erosion to total area for each option and Equation (1) (Mohammad Khan, 2009). In the next stage, EXPERT CHOICE was used to calculate the relative weight of each option.

$$
P=\Delta A \times 0.08+1
$$

Where $P$ : Preference of options relative to each other and $\Delta A$ : differences in areas of regions with erosion in each option.

For assigning weights to the indices, the erosion-prone options were specified in each index. Then, the ratio of the erosion-prone area in a region where erosion had occurred, to total area of erosion facies, was calculated. Finally, a table was completed for preference of each index, and the weight of each index was calculated. In order to assign weights to the criteria, the corresponding indices to each criterion with the highest percentage of erosion area in the previous stage were selected as the dominant indices. These were then used to complete the pair-wise comparison matrix of criteria, and to finally calculate the weight of each criterion. The combined weight of options was calculated by multiplying the weight of each category by its higher category. Then, the sum of the weights for options of each index was calculated, while the weight of each criterion was calculated by the sum of weights for indices of that criterion (Tables 2 and 3).

Table 2. Combined weights of options, indices and criteria at the reference time before project implementation (1994).

\begin{tabular}{|c|c|c|c|c|c|}
\hline \multicolumn{2}{|c|}{ Options weight } & \multicolumn{2}{|c|}{ Indicators weight } & \multicolumn{2}{|c|}{ Criteria Weight } \\
\hline$<30$ & 0.04 & & & \multirow{6}{*}{ Vegetation } & \multirow{6}{*}{0.075} \\
\hline $30-75$ & 0.007 & Coverage & 0.057 & & \\
\hline$>75$ & 0.01 & percentage & & & \\
\hline Tree & 0.003 & \multirow{3}{*}{ Germination form } & \multirow{3}{*}{0.018} & & \\
\hline Shrubs & 0.012 & & & & \\
\hline Grass & 0.003 & & & & \\
\hline Loam & 0.008 & \multirow{6}{*}{ Soil texture } & \multirow{6}{*}{0.034} & \multirow{9}{*}{ Soil } & \multirow{9}{*}{0.066} \\
\hline Sandy Loam & 0.01 & & & & \\
\hline Clay Loam & 0.005 & & & & \\
\hline Clay & 0.007 & & & & \\
\hline Silty Clay & 0.001 & & & & \\
\hline Loamy Sand & 0.003 & & & & \\
\hline Relatively High & 0.012 & \multirow{3}{*}{ Infiltration } & \multirow{3}{*}{0.032} & & \\
\hline Moderate & 0.008 & & & & \\
\hline Relatively Low & 0.012 & & & & \\
\hline Good Forest & 0.002 & \multirow{7}{*}{ Land use } & \multirow{7}{*}{0.081} & \multirow{7}{*}{ Land use } & \multirow{7}{*}{0.081} \\
\hline $\begin{array}{l}\text { Semi- degraded } \\
\text { forest }\end{array}$ & 0.006 & & & & \\
\hline Degraded forest & 0.023 & & & & \\
\hline Good pasture & 0.01 & & & & \\
\hline Village & 0.014 & & & & \\
\hline Garden & 0.024 & & & & \\
\hline Rock & 0.002 & & & & \\
\hline
\end{tabular}




\begin{tabular}{|c|c|c|c|c|c|}
\hline Q2 & 0.1 & \multirow{7}{*}{ Geology } & \multirow{7}{*}{0.253} & \multirow{7}{*}{ Geology } & \multirow{7}{*}{0.253} \\
\hline Qs & 0.03 & & & & \\
\hline Javaherdeh & 0.04 & & & & \\
\hline Shemshak & 0.03 & & & & \\
\hline Nesen & 0.009 & & & & \\
\hline Tizkooh & 0.008 & & & & \\
\hline Elika & 0.036 & & & & \\
\hline $800-900$ & 0.035 & \multirow{4}{*}{ Precipitation } & & \multirow{6}{*}{ Climate } & \multirow{6}{*}{0.256} \\
\hline $900-1000$ & 0.02 & & 0.155 & & \\
\hline $1000-1100$ & 0.026 & & & & \\
\hline $1100-1200$ & 0.074 & & & & \\
\hline Rain & 0.03 & \multirow{2}{*}{$\begin{array}{l}\text { Precipitation } \\
\text { form }\end{array}$} & \multirow[b]{2}{*}{0.11} & & \\
\hline Snow & 0.08 & & & & \\
\hline$<10$ & 0.05 & \multirow{5}{*}{ Slope } & \multirow{5}{*}{0.21} & \multirow{9}{*}{ Physiographic } & \multirow{9}{*}{0.254} \\
\hline $10-20$ & 0.06 & & & & \\
\hline $20-30$ & 0.02 & & & & \\
\hline $30-40$ & 0.04 & & & & \\
\hline$>40$ & 0.04 & & & & \\
\hline $\mathrm{N}$ & 0.01 & \multirow{4}{*}{ Aspect } & \multirow{4}{*}{0.044} & & \\
\hline $\mathrm{E}$ & 0.008 & & & & \\
\hline $\mathrm{S}$ & 0.015 & & & & \\
\hline W & 0.011 & & & & \\
\hline
\end{tabular}

Table 3. Combined weights of options, indices and criteria at the reference time after project implementation (2014).

\begin{tabular}{|c|c|c|c|c|c|}
\hline \multicolumn{2}{|c|}{ Options weight } & \multicolumn{2}{|c|}{ Indicators weight } & \multicolumn{2}{|c|}{ Criteria Weight } \\
\hline$<30$ & 0.018 & & & \multirow{6}{*}{ Vegetation } & \multirow{6}{*}{0.089} \\
\hline $30-75$ & 0.042 & Coverage & 0.07 & & \\
\hline$>75$ & 0.01 & percentage & & & \\
\hline Tree & 0.004 & \multirow{3}{*}{$\begin{array}{l}\text { Germination } \\
\text { form }\end{array}$} & \multirow{3}{*}{0.019} & & \\
\hline Shrubs & 0.01 & & & & \\
\hline Grass & 0.005 & & & & \\
\hline Loam & 0.012 & & \multirow{6}{*}{0.034} & & \multirow{9}{*}{0.066} \\
\hline Sandy Loam & 0.008 & \multirow{5}{*}{ Soil texture } & & & \\
\hline Clay Loam & 0.005 & & & & \\
\hline Clay & 0.007 & & & & \\
\hline Silty Clay & 0.002 & & & Soll & \\
\hline Loamy Sand & 0.003 & & & & \\
\hline Relatively High & 0.011 & \multirow{3}{*}{ Infiltration } & \multirow{3}{*}{0.032} & & \\
\hline Moderate & 0.015 & & & & \\
\hline Relatively Low & 0.006 & & & & \\
\hline Good Forest & 0.003 & \multirow{7}{*}{ Land use } & \multirow{7}{*}{0.045} & \multirow{7}{*}{ Land use } & \multirow{7}{*}{0.045} \\
\hline Semi- degraded forest & 0.01 & & & & \\
\hline Moderate pasture & 0.017 & & & & \\
\hline Good pasture & 0.005 & & & & \\
\hline Village & 0.007 & & & & \\
\hline Garden & 0.002 & & & & \\
\hline Rock & 0.001 & & & & \\
\hline Q2 & 0.083 & \multirow{7}{*}{ Geology } & \multirow{7}{*}{0.269} & & \multirow{6}{*}{0.269} \\
\hline Qs & 0.035 & & & & \\
\hline Javaherdeh & 0.017 & & & & \\
\hline Shemshak & 0.022 & & & & \\
\hline Nesen & 0.075 & & & & \\
\hline Tizkooh & 0.017 & & & & \\
\hline Elika & 0.02 & & & & Geology \\
\hline $600-700$ & 0.009 & \multirow{6}{*}{ Precipitation } & \multirow{6}{*}{0.189} & & \multirow{4}{*}{0.269} \\
\hline $700-800$ & 0.03 & & & & \\
\hline $800-900$ & 0.035 & & & & \\
\hline $900-1000$ & 0.03 & & & & \\
\hline $1000-1100$ & 0.015 & & & & Climate \\
\hline $1100-1200$ & 0.07 & & & & \\
\hline
\end{tabular}




\begin{tabular}{|c|c|c|c|c|c|}
\hline $\begin{array}{l}\text { Rain } \\
\text { Snow }\end{array}$ & $\begin{array}{l}0.02 \\
0.06\end{array}$ & $\begin{array}{l}\text { Precipitation } \\
\text { form }\end{array}$ & 0.08 & & \\
\hline$<10$ & 0.1 & & \multirow{5}{*}{0.2} & \multirow{9}{*}{ Physiographic } & \multirow{9}{*}{0.256} \\
\hline $10-20$ & 0.02 & Slope & & & \\
\hline $20-30$ & 0.02 & & & & \\
\hline $30-40$ & 0.02 & & & & \\
\hline$>40$ & 0.04 & & & & \\
\hline $\mathrm{N}$ & 0.006 & \multirow{4}{*}{ Aspect } & \multirow{4}{*}{0.056} & & \\
\hline $\mathrm{E}$ & 0.022 & & & & \\
\hline $\mathrm{S}$ & 0.025 & & & & \\
\hline W & 0.003 & & & & \\
\hline
\end{tabular}

The weights were assigned to erosion facies through expert opinions as acquired via a questionnaire (Table 4).

Table 4. Weights of erosion facies.

\begin{tabular}{|c|c|c|c|c|c|c|c|c|}
\hline Facies & $\begin{array}{c}\text { Regular } \\
\text { hillside }\end{array}$ & $\begin{array}{c}\text { Sheet } \\
\text { erosion }\end{array}$ & $\begin{array}{c}\text { Rill } \\
\text { erosion }\end{array}$ & $\begin{array}{c}\text { Gully } \\
\text { erosion }\end{array}$ & $\begin{array}{c}\text { Massive } \\
\text { erosion }\end{array}$ & $\begin{array}{c}\text { Stream - } \\
\text { bank erosion }\end{array}$ & $\begin{array}{c}\text { Rocky } \\
\text { protrusions }\end{array}$ & $\begin{array}{l}\text { Rock } \\
\text { mass }\end{array}$ \\
\hline weight & 0.03 & 0.063 & 0.087 & 0.221 & 0.388 & 0.129 & 0.05 & 0.028 \\
\hline
\end{tabular}

\section{Mapping of erosion intensities}

After calculating the combined weights, the information layers on indices were prepared, based on the combined weights of their options. Then, Equation (2) was used to compile the erosion intensity map (Metternicht and Gonzalez, 2005).

$$
\mathrm{GM}=(\mathrm{P}+\mathrm{C}+\mathrm{G}+\mathrm{S}+\mathrm{V}+\mathrm{L}) * \text { Facies }
$$

Where GM: Erosion intensity, $P$ : Physiography, $C$ : Climate, $G$ : Geology, $S$ : Soil, $V$ : Vegetation, and $L$ : Land use.

All these layers and maps were generated for the two reference points in time, i.e. before the implementation of soil and water conservation projects (1994) and after their implementation (2014).

\section{Evaluation of soil and water conservation projects}

The projects implemented in the region were evaluated by firstly preparing maps of the working units through integration of geology, erosion and facies layers, slope, and aspect contributions. The maps included 39 homogeneous units. Weighted average of erosion intensity in each working unit was calculated by matching the erosion intensity map to the working unit's map, while preparing an average erosion map for each working unit (Fig. 2 and 3). Fig. 4 shows a graph of erosion intensity change. 


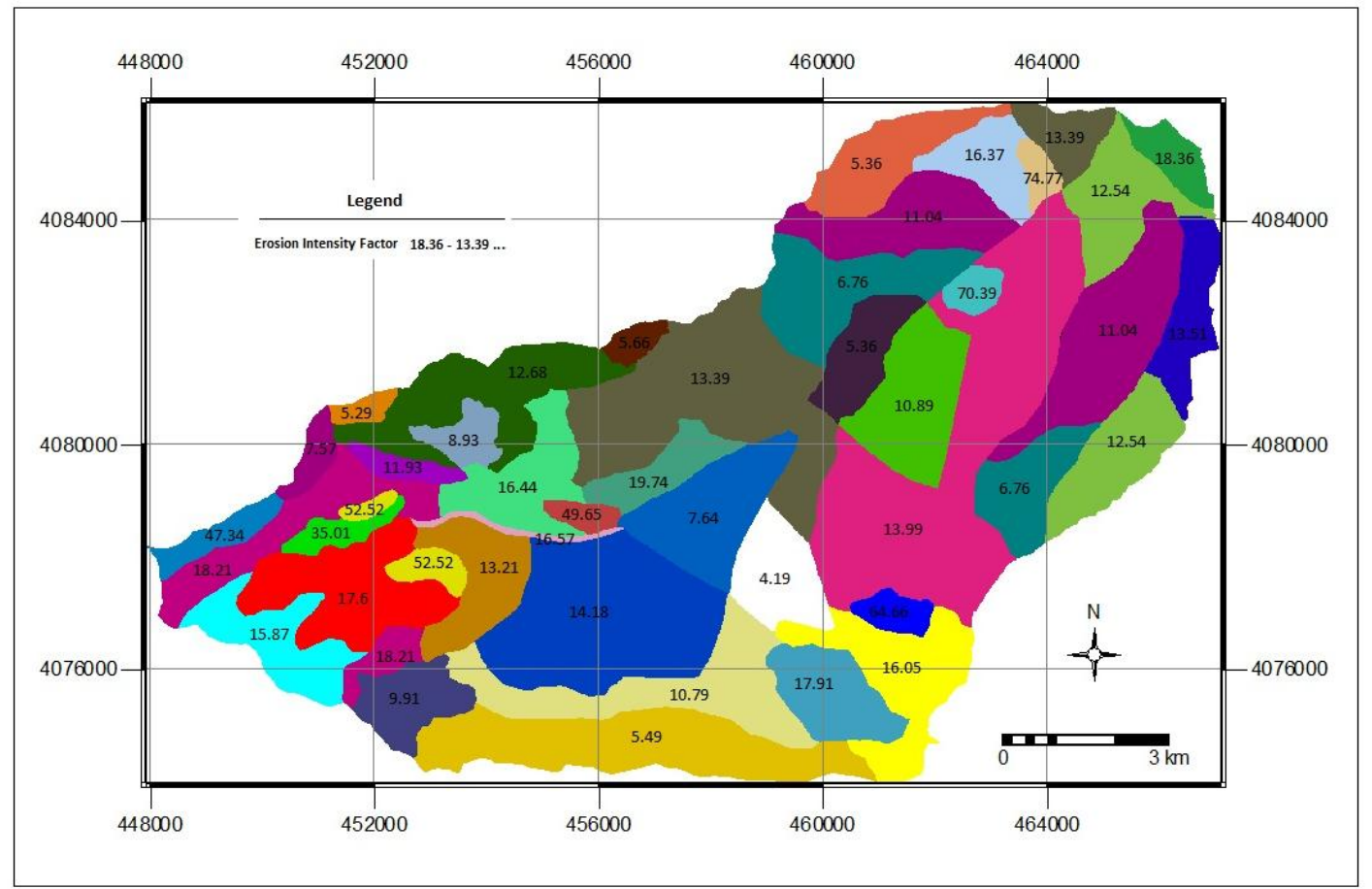

Figure 2. Erosion intensity map at the base time before project implementation (1994).

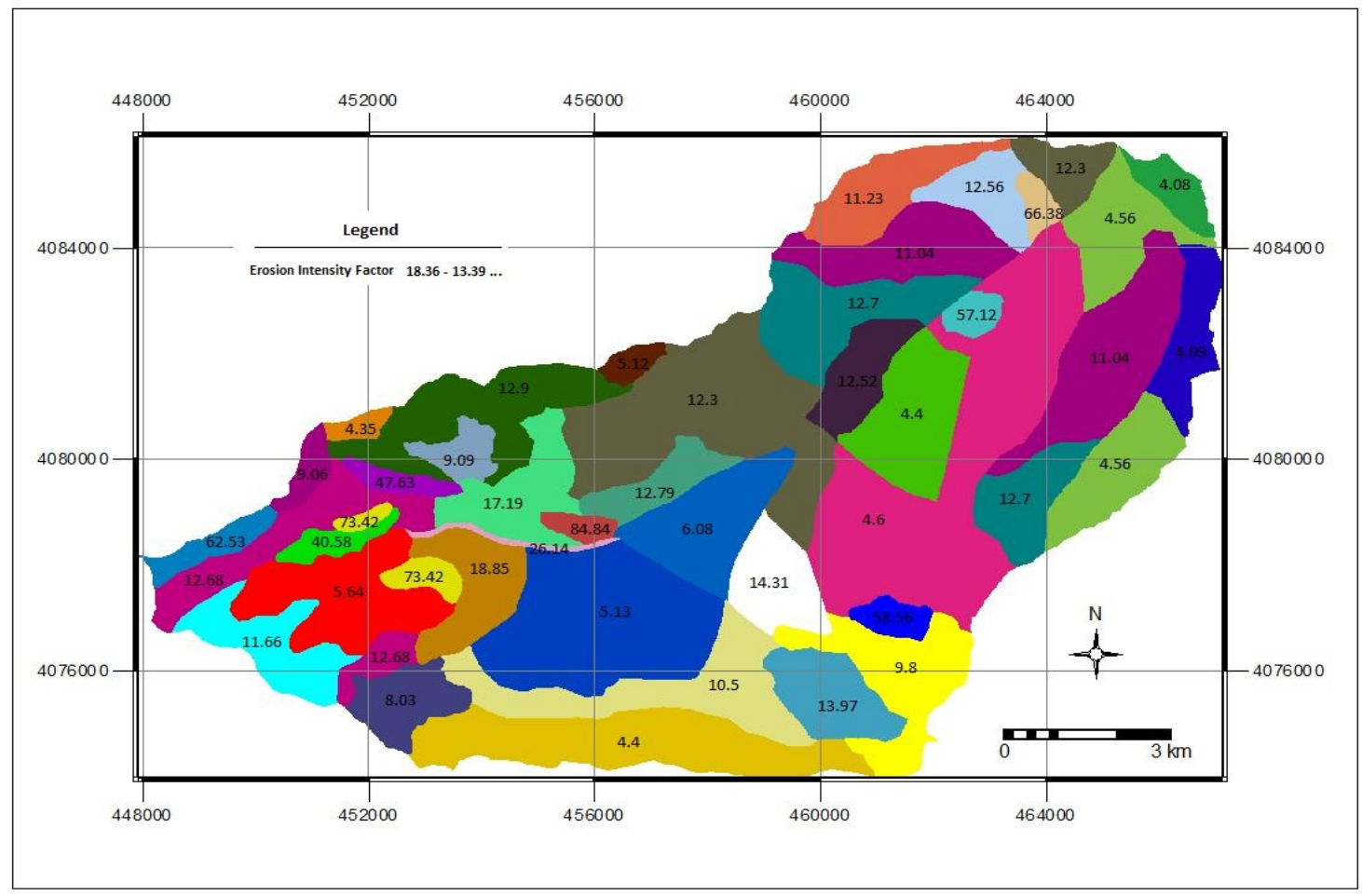

Figure 3. Erosion intensity map at the base time after project implementation (2014). 


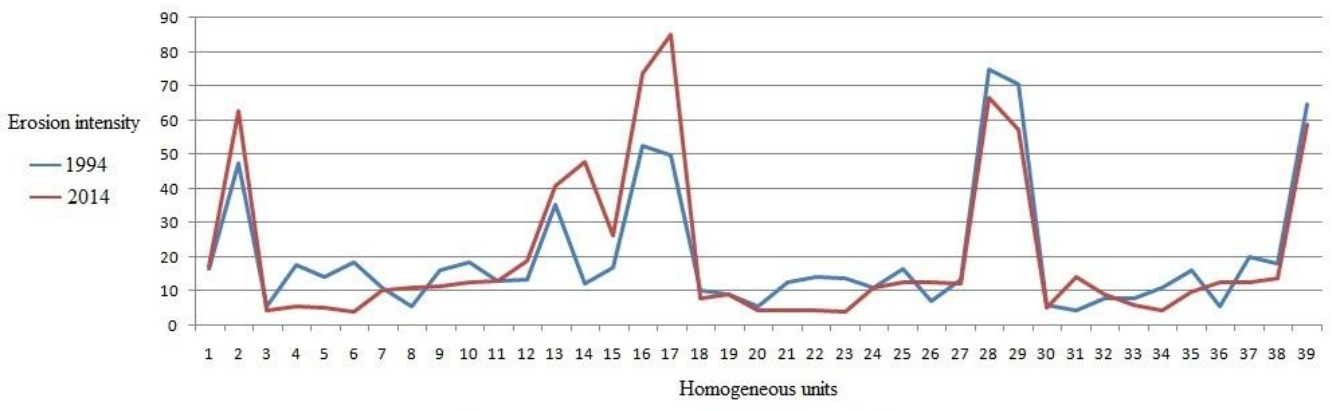

Figure 4. Erosion intensity change

By comparing the maps of erosion intensity at the two reference times, it was revealed whether the erosion trend in each working unit was positive or negative; see Fig. 5.

The maps of erosion trends across the region were matched against the maps of soil and water conservation projects, indicating how effective each project was in the working units.

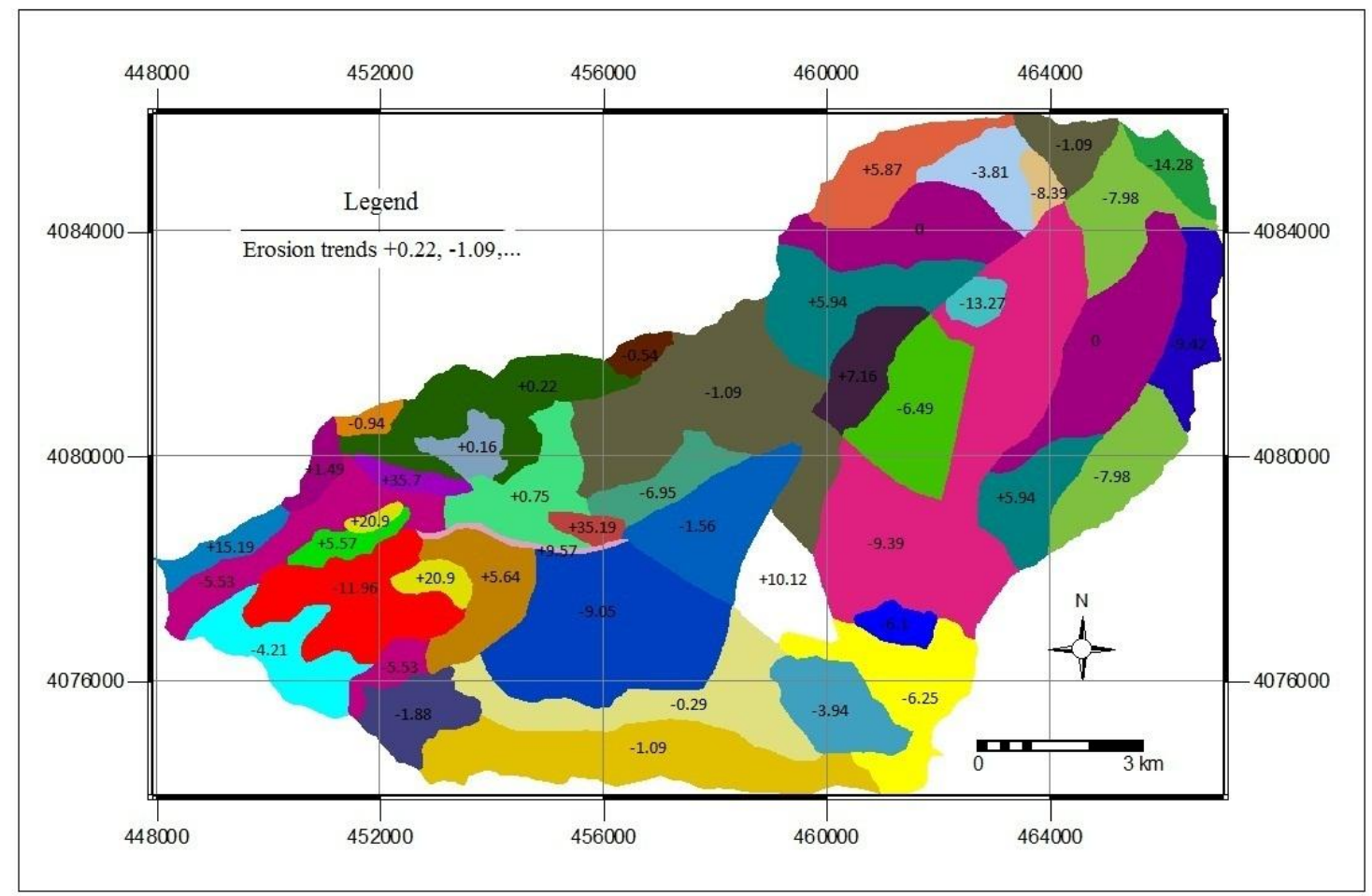

Figure 5. Map of erosion trends.

\section{Statistical analysis}

By comparing the average values for two dependent groups (paired sample t-test), the erosion trends in the working units were tested at the two reference times, returning 
a p-value of 0.05 , so that the significances of the efficacies of the projects were statistically determined.

\section{Results and discussion}

The map of the erosion trend was compiled by matching the erosion intensity map at the two reference times under consideration (Fig. 5).

Being a dimensionless number, erosion intensity was multiplied by 1000 to gain a better understanding and better representation of possible differences. Fig. 6 shows a graph of erosion trends.

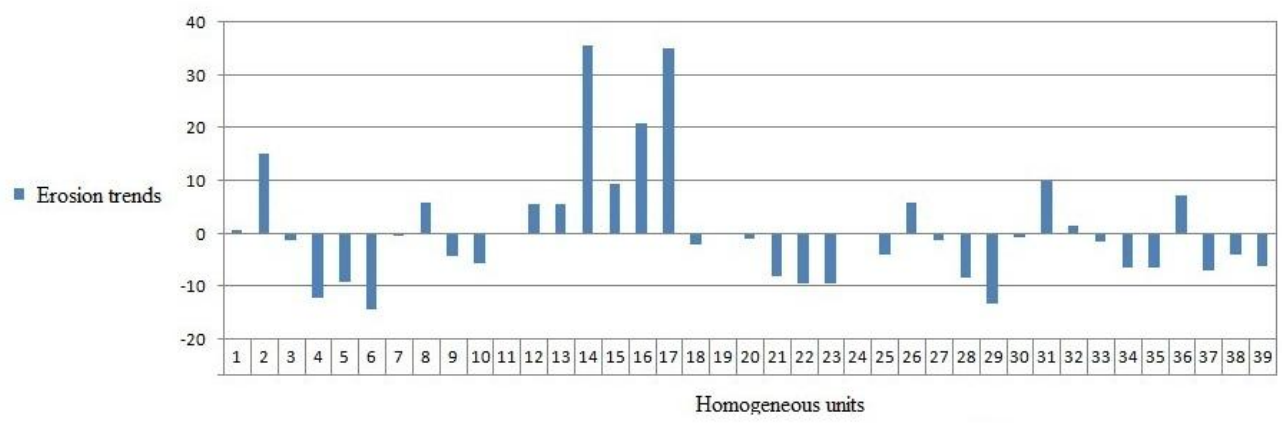

Figure 6. Erosion trends

The erosion trend map was matched against the map of projects implemented in the region, so that in each unit, effectiveness of various projects on erosion trend was indicated. Table 5 reports the results of statistical analysis at p-value 0.05 by comparing average values for the two dependent groups.

Table 5. The results of statistical analysis (paired samples test).

\begin{tabular}{|c|c|c|c|c|c|c|c|c|c|}
\hline \multirow{3}{*}{\multicolumn{2}{|c|}{ Paired Samples Test }} & \multicolumn{5}{|c|}{ Paired Differences } & \multirow[t]{3}{*}{$\mathbf{t}$} & \multirow[t]{3}{*}{ df } & \multirow[t]{3}{*}{ Sig. (2-tailed) } \\
\hline & & \multirow[t]{2}{*}{ Mean } & \multirow[t]{2}{*}{$\begin{array}{c}\text { Std. } \\
\text { Deviation }\end{array}$} & \multirow[t]{2}{*}{$\begin{array}{l}\text { Std. Error } \\
\text { Mean }\end{array}$} & \multicolumn{2}{|c|}{$\begin{array}{l}95 \% \text { Confidence Interval } \\
\text { of the Difference }\end{array}$} & & & \\
\hline & & & & & Lower & Upper & & & \\
\hline Pair 1 & $\begin{array}{l}\text { GM1994 - } \\
\text { GM2014 }\end{array}$ & -.06426 & 1.11397 & .17838 & -.42536 & .29685 & -.360 & 38 & .721 \\
\hline
\end{tabular}

Assuming that $\mathrm{Sig}>\alpha(0.721>0.05)$, the null hypothesis $\left(\mathrm{H}_{0}\right)$, i.e. equality of average values of the two groups, was proven, indicating no significant difference in erosion intensities before and after project implementation across the region. Therefore, the soil and water conservation projects implemented in the region have failed to have any significant effect on erosion intensity at Safaroud watershed. Fatollahi (2008) and Eisazadeh et al. (2012) in the evaluation of soil and water conservation projects came to similar conclusions.

Unlike the statistical results, erosion intensities decreased in 18 units out of 39 working units, most of which have been located in forests. Further, erosion increased in 15 units, while it remained unchanged in one unit at the two reference times. Although 18 out of the 39 working units indicated decreasing erosion trends, the downtrend rates 
were insignificant. However, the increasing erosion trends in 15 units were extremely high. Most of the units exhibiting extreme erosion intensities were located in rural areas, particularly the tourist-attracting village called Javaherdeh as well as the surrounding villages. These regions host human activities such as road construction and development of rural areas.

There is a road running from Javaherdeh Village to the end of the watershed, on top of which the road meets an adjacent watershed called Chalakroud, at an altitude of 3,560 metres. Along this road, there is a production plant for sand. Extreme erosion is observed around the road. Although numerous structures (soil-saving dam) have been established inside the watersheds to curtail the destructive effect of the road, there is still a visible erosion trend in the working units across the region. Fatollahi (2008), Sidle (2010) and Zemke (2016) in their studies recognized that road construction is an important factor in erosion.

Nonetheless, the erosion trend was found to be decreasing in most parts of the forestcovered parts of the watershed. The exploitation rate has been curtailed in these areas in response to the implementation of programmes to take livestock out of the forests. Most residents of these areas are engaged in businesses providing services to travellers and tourists. Although there are forest exploitation companies operating in the region, protective projects implemented in forests have proved effective.

The region under study is a tourist attraction in Iran, hosting the tourist village Javaherdeh, which attracts a large number of tourists every year. Therefore, it is crucial to implement tourist projects in the context of sustainable development in the region, since the greatest erosion trends were observed in the units adjacent to Javaherdeh and corresponding villages.

\section{REFERENCES}

[1] Ahmadi, H. (2006): Applied Geomorphology (Vol. 1): Water Erosion. - Tehran University Press, Teheran.

[2] Ahmadi, H., Maleki, M., Jafari, M., Ghodusi, J., Azarnivand, H. Mosayebi, M. (2009): Quantification of Qualitative Geomorphology Method for Water Erosion Estimation (Case Study: Three Sub-Watersheds of Latian Dam Basin). - Iranian Journal of Natural Resources 61(4): 775-795.

[3] Akgun, A., Dag, S. Bulut, F. (2008): Landslide Susceptibility Mapping for a LandslideProne Area (Findikli, NE of Turkey) by Likelihood-Frequency Ratio and Weighted Linear Combination Models. - Environmental Geology 54(6): 1127-1143.

[4] Angabini, S. (2014): A New Model of Regional Erosion and Sediment at Jegin Watershed by Comparing Experimental Models, Geomorphology and Intelligent Systems (Fuzzy Logic, Neural Network). - Ph.D thesis, Science and Research Branch of Tehran, Teheran.

[5] Arab Khedri, M. (2014): A review of water erosion intensity and sediment yield in Iran.Extension and Development of Watershed Management, Tehran 4(2): 23-30.

[6] Ayalew, L., Yamagishi, H., Ugawa, N. (2004): Landslide Susceptibility Mapping Using GIS-based Weighted Linear Combination, the Case in Tsugawa Area of Agano River, Niigata Prefecture, Japan. - Landslides 1(1): 73-81.

[7] Barredo, J., Benavides, A., Hervás, J., Van Westen, C. J. (2000): Comparing Heuristic Landslide Hazard Assessment Techniques Using GIS in the Tirajana Basin, Gran Canaria Island, Spain. - International Journal of Applied Earth Observation and Geoinformation 2(1): 9-23. 
[8] Chacón, J., Irigaray, C., Fernandez, T., El Hamdouni, R. (2006): Engineering Geology Maps: Landslides and Geographical Information Systems. - Bulletin of Engineering Geology and the Environment 65(4): 341-411.

[9] Conoscenti, C., Di Maggio, C., Rotigliano, E. (2008): Soil Erosion Susceptibility Assessment and Validation Using a Geostatistical Multivariate Approach: a Test in Southern Sicily. - Natural Hazards 46(3): 287-305.

[10] Eisazadeh, L., Sokouti, R., Homaee, M., Pazira, E. (2012): Comparison of Empirical Models to Estimate Soil Erosion and Sediment Yield in Microcatchments. - Eurasian Journal of Soil Science 1(1): 28-33.

[11] Engineers, K. C. (1994): Extensive Watershed Studies on Safaroud, Sari, Iran. - Jahad Engineering Services Co.

[12] Fatollahi, A. (2008): Evaluation the Effect Watershed Management on Sediment Decrease in Taham Dam Basin (Part of Zanjanrood Basin). - 5th National Seminar on Watershed Management, Agriculture and Natural Resource University, Gorgan, Iran.

[13] Gournellos, T., Evelpidou, N., Vassilopoulos, A. (2004): Developing an Erosion Risk Map Using Soft Computing Methods (Case Study at Sifnos Island). - Natural Hazards 31(1): 63-83.

[14] He, D. (1999): Modeling of Dominating Factors to Soil and Water Conservation. - Fujian Forestry College Trans. 19(1): 26-29.

[15] Hudson, N. (1981): Instrumentation for Studies of the Erosive Power of Rainfall. Erosion and Sediment Transport Measurement (Proceedings of the Florance Symposium, June 1981). IAHS Publication Number 133 pp. 372-382.

[16] Jozefaciuk, C., Jozefaciuk, A. (1993): Gullies net density as a factor of water system deformation in Vistula River basin. - In: Banasik, K., Zbikowski, A. (eds.). Runoff and Sediment Yield Modelling. Warsaw Agricultural University Press, Warsaw, pp. 169-74.

[17] Lee, S., Ryu, J.-H., Lee, M.-J., Won, J.-S. (2006): The Application of Artificial Neural Networks to Landslide Susceptibility Mapping at Janghung, Korea. - Mathematical Geology 38(2): 199-220.

[18] Masoudi, M., Patwardhan, A., Gore, S. (2006): Risk Assessment of Water Erosion for the Qareh Aghaj Subbasin, Southern Iran. - Stochastic Environmental Research and Risk Assessment 21(1): 15-24.

[19] Metternicht, G. Gonzalez, S. (2005): Fuero: Foundations of a Fuzzy Exploratory Model for Soil Erosion Hazard Prediction. - Environmental Modelling \& Software 20(6): 715-728.

[20] Mohammad Khan, Sh. (2009): Quantitative Estimation of Erosion and Sediment through GIS; Case Study of Latian Watershed. - Ph.D. Thesis, University of Tehran.

[21] Mosayebi, M., Ahmadi, H. Maleki, M. (2008): Evaluation of Quantitative Geomorphology Model (IRSEEM) for Watershed Erosion Estimation (Case Study: Taleghan Watershed). - 5th National Seminar on Watershed Management, Agriculture and Natural Resource University, Gorgan, Iran.

[22] Moussa, R., Voltz, M., Andrieux, P. (2002): Effects of the Spatial Organization of Agricultural Management on the Hydrological Behaviour of a Farmed Catchment during Flood Events. - Hydrological Processes 16(2): 393-412.

[23] Nielsen, T., Wrigth, R., Vlasic, T., Spangle, W. (1979): Relative Slope Stability and Land-Use Planning in the San Francisco Bay Region: Professional Paper 944. - U.S. Government Printing Office, USA.

[24] Oh, H.-J., Lee, S., Chotikasathien, W., Kim, C. H., Kwon, J. H. (2009): Predictive Landslide Susceptibility Mapping Using Spatial Information in the Pechabun Area of Thailand. - Environmental Geology 57: 641-651.

[25] Onyando, J., Kisoyan, P., Chemelil, M. (2005): Estimation of Potential Soil Erosion for River Perkerra Catchment in Kenya. - Water Resources Management 19(2): 133-143.

[26] Rooseboom, A., Annandale, G. (1981): Techniques Applied in Determining Sediment Loads in South African Rivers. - Erosion and Sediment Transport Measurement 
(Proceedings of the Florance Symposium, June 1981). IAHS Publication Number 133. pp. 219-224.

[27] Saaty, T. L. (2008): Decision Making with the Analytic Hierarchy Process. International Journal of Services Sciences 1(1): 83-98.

[28] Sar, N., Khan, A., Chatterjee, S., Das, A., Mipun, B. S. (2016): Coupling of analytical hierarchy process and frequency ratio based spatial prediction of soil erosion susceptibility in Keleghai river basin, India. - International Soil and Water Conservation Research http://www.sciencedirect.com/science/article/pii/S2095633915301246 (withdrawn)

[29] Sidle, R. C. (2010): Hydrogeomorphic Processes in Temperate and Tropical Forests: Effects of Land Use and Scale. - Geography Compass 4(8): 1115-1132.

[30] Souchère, V., Cerdan, O., Dubreuil, N., Le Bissonnais, Y., King, C. (2005): Modelling the impact of agri-environmental scenarios on runoff in a cultivated catchment (Normandy, France). - Catena 61(2-3): 229-240.

[31] Tenge, A. J. M. (2005): Participatory Appraisal for Farm-Level Soil and Water Conservation Planning in West Usambara highlands, Tanzania. - Wageningen University and Research Centre. Wageningen, Netherlands.

[32] Teshome, A., De Graaff, J. Stroosnijder, L. (2014): Evaluation of Soil and Water Conservation Practices in the North-Western Ethiopian Highlands Using Multi-Criteria Analysis. - Frontiers in Environmental Science 2: 60.

[33] Tian, Y., Zhou, Y., Wu, B., Zhou, W. (2009): Risk Assessment of Water Soil Erosion in Upper Basin of Miyun Reservoir, Beijing, China. - Environmental Geology 57(4): 937-942.

[34] Vezina, K., Bonn, F., Van, C. P. (2006): Agricultural Land-Use Patterns and Soil Erosion Vulnerability of Watershed Units in Vietnam's Northern Highlands. - Landscape ecology 21(8): 1311-1325.

[35] Wu, Q., Wang, M. (2007): A Framework for Risk Assessment on Soil Erosion by Water Using an Integrated and Systematic Approach. - Journal of Hydrology 337(1-2): 11-21.

[36] Yagi, H. (2003): Development of Assessment Method for Landslide Hazardness by AHP. Abstract Volume of the 42nd Annual Meeting of the Japan Landslide Society, pp. 209-212.

[37] Zemke, J. J. (2016): Runoff and Soil Erosion Assessment on Forest Roads Using a Small Scale Rainfall Simulator. - Hydrology 3(3): 25. 